University of Nebraska - Lincoln

DigitalCommons@University of Nebraska - Lincoln

20th \& 21st Century French and Francophone Modern Languages and Literatures, Department Studies International Colloquium

4-2020

\title{
Claiming the Land: The Spanish Presence in Colonial Algeria
}

Lavinia Horner

Kansas State University, Ihorner@ksu.edu

Follow this and additional works at: https://digitalcommons.unl.edu/ffsc2020

Part of the Comparative Literature Commons, French and Francophone Literature Commons, and the Other French and Francophone Language and Literature Commons

Horner, Lavinia, "Claiming the Land: The Spanish Presence in Colonial Algeria" (2020). 20th \& 21st Century French and Francophone Studies International Colloquium. 14.

https://digitalcommons.unl.edu/ffsc2020/14

This Article is brought to you for free and open access by the Modern Languages and Literatures, Department of at DigitalCommons@University of Nebraska - Lincoln. It has been accepted for inclusion in 20th \& 21st Century

French and Francophone Studies International Colloquium by an authorized administrator of DigitalCommons@University of Nebraska - Lincoln. 


\section{Claiming the Land:}

The Spanish Presence in Colonial Algeria

Lavinia Horner - Kansas

State University 

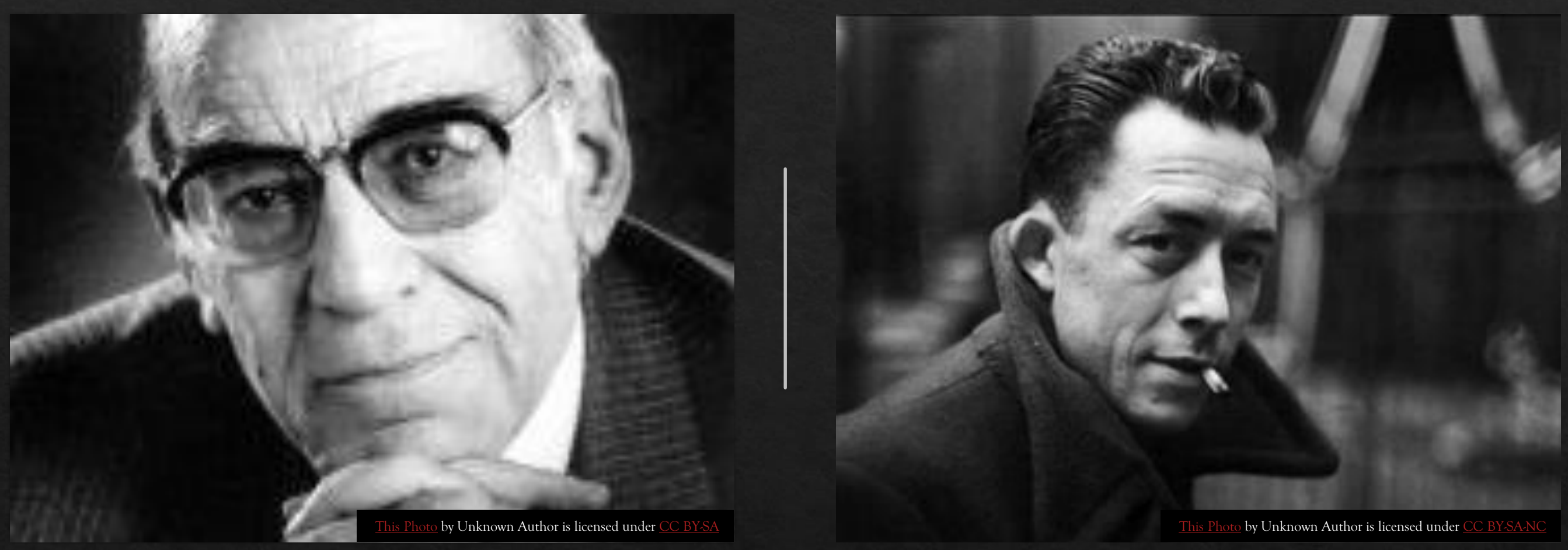

\section{Emmanuel Roblès \& Albert Camus}




\title{
The Spanish Presence in Colonial Algeria
}

\section{Emmanuel Roblès Albert Camus}

$\diamond$ Both parents - Spanish descent

\author{
$\diamond$ Father - French \\ $\diamond$ Mother - Spanish descent
}




\section{Argument}

$\diamond$ Roblès' and Camus' literary as well as epistolary testimonies disrupt the FrenchArab/Berber dichotomous colonial narrative, thus expanding pied-noir legacies and unraveling little-known aspects of the mostly forgotten, yet indelible Spanish presence in colonial Algeria. 
The theoretical framework

$\diamond$ It follows a multidisciplinary approach drawing from literature, psychology and legal studies to investigate how assertive literary testimonies can switch perspectives on what will be remembered. 


\section{Literary/epistolary primary sources regarding the importance of trials $\&$ testimonies}
$\diamond$ Roblès:
$\diamond$ Camus:
$\diamond$ Jeunes saisons - Autobiography
$\diamond$ L'étranger (1942) (1961)
$\diamond$ La peste (1947)
$\diamond$ Saison violente (1974)
$\diamond$ Camus, frère de soleil (1995) 


\section{Some secondary sources}

$\diamond$ Kamel Daoud - Meursault: contre-enquête

$\diamond$ Guy Dugas - Emmanuel Roblès et l'hispanité en Oranie

$\diamond$ Alain Vircondelet - Albert Camus fils d'Alger

$\diamond$ Lamine Benallou - Oran et l'Espagne au XXème siècle

$\diamond$ Jane Blocker - Seeing Witness: Visuality and the Ethics of Testimony

$\diamond$ Ana Douglass; Thomas Vogler - Witness and Memory: The Discourse of Trauma

$\diamond$ Stevan Weine - Testimony after Catastrophe: Narrating the Traumas of Political Violence

$\diamond$ Maria Antonia Garces - Cervantes in Algiers: A Captive's Tale

$\diamond$ William Booth - Communities of Memory: On Witness, Identity and Justice 


\section{The Spanish presence in Algeria}

$\diamond$ Before the French colonization of the 19th century that complicated identities and heritages, the Spanish presence was felt in Algeria as early as the 16th century:

La source d'inspiration qui servit à l'expansion espagnole vers le nord de l'Afrique fut le testament D'Isabelle la Catholique. L'artifice et maître d'œuvre de la conquête fut le Cardinal Francisco Jiménez de Cisneros, confesseur d'Isabelle la Catholique. Mers-el-Kébir tomba sous la domination espagnole en 1505, Oran en 1509 et en 1510, ce fut pratiquement toute la côte algéro-marocaine ainsi que Bougie, aujourd'hui Bejaïa, Tripoli avec un peu plus tard des incursions vers l'intérieur, conquérant par exemple le Royaume de Tlemcen en 1543 (Benallou - Oran et l'Espagne au XXème siècle, Kindle edition, Location 463). 


\section{Algeria, $16^{\text {th }}$ century - Miguel de Cervantes' experience and literary testimonies}

$\diamond$ Miguel de Cervantes, at the age of twenty-eight, was captured and imprisoned in Algeria. This experience highly influenced his themes related to captivity or self-captivity/delusion in his literary works following this traumatic ordeal. According to Maria Antonia Garces, the 16th century Mediterranean space represented a site of complex exchanges and interactions between North Africa and Christian Europe, especially Spain (Cervantes in Algiers: A Captive's Tale, 4). In her narrative, Garces focuses on the tumultuous case of Cervantes:

"Returning to Spain after fighting in the Battle of Lepanto and other Mediterranean campaigns against the Turks, soldier Miguel de Cervantes was captured by Barbary pirates and taken as a captive to Algiers. [...] His oeuvre is haunted by images of captivity: cages of all sizes, Christian captives, gallery slaves, and female prisoners, some used as translators, others confined to special prisons" (Garces, 1). 


\section{Camus' hybrid heritage}

$\diamond \underline{\text { French }}$ - highly debated and controversial heritage

$\diamond$ Spanish - little known 


\section{On Camus' Spanish heritage}

\section{Vircondolet, Albert Camus fils d'Alger}

$\diamond$ « Il [Camus] participe à des débats, des rencontres, mais se concentre sur la guerre d'Espagne et la montée des intolérances en Europe. Sa création va se calquer sur ces contradictions, qui deviendront des lignes de force de sa philosophie : l'envers et l'endroit, le oui et le non, l'exil et le royaume, la lumière et l'ombre, etc » (153). Vircondelet refers here to debates regarding the events of the 1940's in Algeria that were slowly escalating to the outburst of the War for Independence
Roblès, Camus, frère de soleil (epistolary work, contains letter exchanges between Roblès and Camus)

$\diamond$ «Albert Camus avait au plus haut degré le sens de l'amitié. Avec ceux qu'il estimait il se montrait toujours attentive et d'un complet dévouement. A ceux qui trahissaient sa confiance la porte se fermait et toute réconciliation devenait aléatoire, sinon impossible. Je reconnais là ce sang d'Espagne qui nous était commun » (9). 


\section{Camus' interest in his Spanish heritage}

\section{Roblès:}

$\diamond$ "Plus tard, il [Camus] me demandera des leçons d'espagnol, ce qui ne durera guère en raison de mes servitudes militaires, surtout à l'approche de l'affaire de Munich » (Camus, frère de soleil, 14).

$\diamond$ «Camus m'écoutait (Fernando de Roja était loin à présent) avec une attention mêlée d'une très visible surprise. Il me dit alors que son parcours - c'est le mot qu'il employa - ressemblait au mien, à cela près que sa mère était d'une famille originaire des Baléares et qu'il n'avait pas, lui non plus, connu son père, tué en 1914 à la bataille de la Marne »(Camus, frère de soleil, 15). 


\section{The importance of testimonies in Camus' literary works (1)}

$\diamond \quad$ Camus foresaw as early as 1947 the omens of change in Algeria and, therefore, the importance that witness and testimony can play in giving shape to historical representations of the past. Consequently, La peste addresses issues of credibility, witnessing and depictions. The first instance in which the credibility of a witness is evoked occurs during the episode when Rieux engages in a discussion with the journalist Rambert:

«Mais il voulait savoir, avant d'aller plus loin, si le journaliste pouvait dire la vérité. - Certes, dit l'autre. - Je veux dire : pouvezvous porter condamnation totale? - Totale, non, il faut bien le dire. Mais je suppose que cette condamnation serait sans fondement. Doucement, Rieux dit qu'en effet une pareille condamnation serait sans fondement, mais qu'en posant cette question, il cherchait seulement à savoir si le témoignage de Rambert pouvait ou non être sans réserves » (18/19). 


\section{The importance of testimonies in Camus' literary works (2)}

$\diamond$ Similar testimonies are invoked in the scene when Cottard's character is discussed. As someone who is condemned by the society for having attempted to commit suicide, Cottard relies on the testimonies of others to help him regain credibility and be perceived as a good person:

« Un jour que le maître d'hôtel l'avait reconduit et aidé à endosser son pardessus, Cottard avait dit à Grand: - C'est un bon garçon, il peut témoigner. - Témoigner de quoi? Cottard avait hésité. - Eh bien, que je ne suis pas un mauvais homme »(La peste, 56). 


\section{On Roblès' Spanish heritage in Algeria}

$\diamond$ Emmanuel Roblès (1914 -1995) was an Algerian writer of Spanish descent born in Oran, during French colonialism. Guy Dugas' Emmanuel Roblès et l'hispanité en Oranie describes Roblès' family history and his attachment to his Spanish heritage:

" Que de plus naturel que ce retour d'Emmanuel Roblès à Oran où il est né le 4 mai 1914 dans une famille originaire d'Espagne, où il a grandi, entouré de femmes - son père, ouvrier du bâtiment, étant décédé dans les mois précédant sa naissance - jusqu'au remariage de sa mère avec (Oh, trahison de l'hispanité!) un ouvrier italien?» (11). 


\section{Roblès: direct testimonies in his literary works (first person "JE")}

$\diamond \quad$ «La même joie, toujours neuve et légère, bondit en moi chaque fois que je retourne à Oran, chaque fois que mon regard, du plus loin, distingue enfin la crête de Santa-Cruz et son vieux fort espagnol, roux et trapu comme un lion couché » (Jeunes saisons, 9)

$\diamond$ «Voici la rue Bruat où je suis né, et la rue de Lourmel que ravinaient les pluies » (Jeunes saisons, 9)

$\diamond \quad$ « $\boldsymbol{J}$ me souviens de leur visage osseux [he describes two guitarists whom he personally heard playing Andalusian songs], de leurs orbites desséchées, de leur expression sévère et triste tandis qu'ils tiraient de leurs instruments des airs joyeux. De ma terrasse, souvent je les écoutais » (Jeunes saisons, 10).

$\diamond \quad$ « Je me souviens d'une marchande d'herbes, une vieille femme qui nous vendait pour un sou cinq ou six feuilles de mûrier destinées à nos vers à soie. Elle s'appelait Doña Maria et l'on ne voyait d'elle, dans la pénombre de sa boutique, qu'une tête ridée et sèche de tortue » ET «Pendus au mur, des sachets de camomille, de salsepareille, de verveine, de queues de cerise exhalaient une odeur rêche et un peu suffocante. De nombreuses images pieuses, violemment colorées, couvraient les intervalles. Tous ces personnages graves qui montraient leurs plaies vives ou leur cœur enflammé m'impressionnaient beaucoup » (Jeunes saisons, 11)

$\diamond \quad$ HE PROVIDES SENSORIAL EVIDENCE (sight, hearing, smell) FOR THE SPANISH PRESENCE IN ALGERIA 


\section{The roles(s) of testimonies}

$\diamond$ Roblès was uncannily aware that the history of his Spanish community was in danger of becoming a blank slate after Algerian independence. His fears are confirmed by Yahia Belaskri who evokes the Spanish presence in Algeria and the amnesia that occurred after 1962:

« Mais qu'en reste-t-il aujourd'hui? La mémoire de la ville en a-t-elle gardé la trace ? Les Oranais en ont-ils gardé la trace ? Qui connaît Emmanuel Roblès, membre de l'Académie Goncourt ? Qui connaît 'le gang des 203' et les républicains espagnols ? Oubliés à jamais, eux et l'Espagne » (chapter in Guy Dugas' Emmanuel Roblès et l'hispanité en Oranie, 33). 


\section{Testimonies $=$ paying a debt}

$\diamond$ In William Booth's Communities of Memory: On Witness, Identity and Justice, Booth invites us to reflect on the fact that testimonies can be interpreted as a responsibility to render justice to the community:

"To neglect the memory of the community, not to preserve and transmit it, in short, not to bear witness to it, would be to damage the group's identity and violate a norm of reciprocity and co-responsibility: the debt, or quasi-contract, entailed by a life-in-common across time between the present in whose hands these memories (partially) rest and the absent past" (XII). 


\section{Roblès on PAYING A DEBT via testimonies}

*** Roblès in « Camus, frère de soleil »: " Cet ouvrage se limite aux souvenirs d'une longue amitié avec Camus, née en septembre 1937 à Alger, alors que j'étais appelé à Blida, ville toute proche, pour mon service militaire. Ces souvenirs sont favorisés par un grand nombre de lettres. Quelques-unes ont été reproduites ici. [...] De Lourmarin, je reçus deux lettres, l'une datée du 7 décembre, l'autre du 28 décembre, alors qu'une semaine plus tard la mort l'attendait sur sa dernière route. Envers Camus, j'ai une dette que ce petit volume, à lui seul, ne saurait acquitter » (Note liminaire)

*** It is interesting to note that the concept of debt employed by Booth in Communities of Memory appears in the above-mentioned statement to reinforce the role that testimonies play in reenacting the past. 


\section{Living history - the role of testimonies}

$\diamond \quad$ Stevan Weine's Testimony after Catastrophe: Narrating the Traumas of Political Violence states that testimonies are not closed narratives, but part of a living history (159). Consequently, these testimonies have the power to continue to influence future decisions regarding past events:

Living history also means that the telling and understanding of history is open, energetic and free. This history is not just static documentation, but interactive conversation. The past is never just past, nor is it just one solitary occurrence. It lives in the present and future and is full of variability, heterogeneity and multiplicity. The future is open and contingent upon the choices of the present. Living history also means that testimony is many kinds of stories, told for multiple purposes, towards different outcomes, in different contexts (159). 


\section{Significance}

$\diamond$ If the understanding of history is not finalized, but open, then bringing to light little-known testimonies extant in both Roblès' and Camus' discourses will serve as a tool for refining discussions regarding intricate heritages in colonial Algeria. 